\title{
CORPORATE SOCIAL RESPONSIBILITY: ANALISIS VARIABEL ANTESEDEN DAN KONSEKUENSI
}

\author{
Masmira Kurniawati \\ Sri Hartini \\ Lilik Rudianto \\ Departemen manajemen FEB Universitas Airlangga \\ Email : masmira_k@yahoo.com
}

\begin{abstract}
This study is exploratory in nature and tries to explain buying consumer behavior of environmental friendly product. Specifically, this study focuses on the antecedents and consequences of corporate social responsibility (CSR) strategy and its impact on marketing outcome using qualitative method. Information on identification of consumer's buying decision process of green marketing products, types of CSR, and marketing outcomes based on customer's perspectives are gathered through in-depth interview.

Nine propositions in relation to the antecedents and consequences of corporate social responsibility strategy from customer perspectives proposed from this study are: (1) consumer perception of CSR activity objectives influences consumer evaluation on CSR activity; (2) consumer evaluation on CSR activity influences consumer buying decision; (3) CSR activity influences customer value; (4) CSR activity creates consumer skepticism toward company; (5) product-related CSR activity which directly impact on consumer will increase consumer attitude toward product; (6) CSR activity influences consumer perception on company's and product's image and increase company as well as brand reputation; (7) consumer judgment on CSR activity influences consumer loyalty; (8) consumer characteristics strengthen the impact of CSR toward consumer buying decision; (9) consumer culture of collectivism influences their attitude toward CSR activity and buying decision of environmental friendly product.
\end{abstract}

Keywords: corporate social responsibility, green marketing, marketing outcome, qualitative method

\section{PENDAHULUAN}

Pada pasar global seperti sekarang ini persaingan antar perusahaan semakin tinggi. Para pemasar harus mempertimbangkan peran yang semakin luas, antara lain tanggung jawab etis dan lingkungan. Dengan kata lain masyarakat menuntut dunia bisnis tidak hanya memikirkan keuntungan perusahaannya, namun harus memperhatikan pihak-pihak lain di sekitarnya. Corporate social responsibility (CSR) yang ada di perusahaan sangat beragam, seperti green product, philanthropy dan cause-related Marketing.

Banyak teori yang menyatakan bahwa strategi perusahaan, termasuk strategi CSR, bertujuan untuk meningkatkan marketing outcome yakni respon positif konsumen, baik kognitif, afektif maupun konatif seperti loyalitas, word of mouth, dan pembelian ulang (Kotler \& Keller, 2012). Banyak studi empiris yang mendukung teori tersebut, antara lain Rahim et al. (2011) membuktikan bahwa philanthropic responsibility akan berpengaruh pada perilaku konsumen dan Ali \& Israr (2012) membuktikan bahwa organization green image berpengaruh signifikan terhadap niat pembelian konsumen. Namun banyak pula studi empiris 
Lilik Rudianto

yang tidak sejalan dengan teori tersebut (Ali et al., 2010; Becker-Olsen et al., 2006). Ide penelitian ini didasarkan adanya theoritical gap pada hubungan kausal antara corporate social responsibility terhadap marketing outcome perusahaan. Penelitian ini dimaksudkan untuk menjembatani theoritical gap tersebut. Adapun temuan yang ditargetkan dalam penelitian ini adalah kejelasan teori mengenai corporate social responsibility, baik kejelasan mengenai variabel anteseden maupun variabel konsekuensi dari strategi tersebut. Untuk menjelaskan teori corporate social responsibility digunakan pendekatan kualitatif untuk menggali/mengeksplorasi variabel-variabel anteseden dan konsekuensi.

\section{LANDASAN TEORI \\ Green Marketing}

Menurut American Marketing Asociation (AMA) green marketing merupakan strategi pemasaran suatu produk yang diasumsikan sebagai produk ramah lingkungan, pengembangan produk yang didesain untuk meminimalisasi dampak negatif pada lingkungan alam, dan meningkatkan kualitasnya. Green marketing merupakan usaha perusahaan dalam memproduksi, mempromosikan, dan mengemas produk dengan cara yang sensitif atau responsif pada masalah lingkungan.

Strategi green marketing meliputi: 1) menawarkan produk yang etis; 2) memproduksi produk yang tidak hanya bertujuan komersil, tapi juga memenuhi kebutuhan konsumen; 3) berkomunikasi dengan jujur dan menyampaikan pesan yang bertanggung jawab; 4) mengembangkan transportasi dan sistem logistik yang tidak menyebabkan polusi serta ramah lingkungan; 5) melakukan advertising dengan jelas dan benar; dan 6) memahami kebutuhan konsumen dan stakeholder di masa depan. Implementasi green marketing melibatkan banyak faktor seperti ecological, political, humanitarian, equality, sustainability, eco-conscious consumers, conservation, fair trade, dan CSR (corporate social responsibility) (Ashok, 2004)

\section{Corporate Social Responsibility}

Terdapat konsep pemasaran baru terkait perhatian pada lingkungan yang dikenal dengan Holistic marketing. Holistic marketing didasarkan pada pengembangan, desain, dan implementasi program pemasaran, proses, dan segala aktivitas yang menunjukkan keluasan dan saling ketergantungan di antaranya (Kotler \& Keller, 2012). CSR (Corporate Social Responsibility) merupakan salah satu bentuk aplikasi dari holistic marketing. Di Indonesia, CSR dinyatakan dalam UU Perseroan Terbatas No. 40 tahun 2007. Pasal 74 ayat 1 undangundang tersebut menyatakan bahwa "Perseroan yang menjalankan kegiatan usahanya di bidang dan atau berkaitan dengan sumber daya alam wajib melaksanakan tanggung jawab sosial dan lingkungan. Dalam Undang-undang No. 25 tahun 2007 tentang penanaman Modal pasal 15 (b) juga menyatakan bahwa "setiap penanam modal berkewajiban melaksanakan tanggung jawab sosial perusahaan."

CSR merupakan bentuk perhatian dari kalangan pebisnis untuk berbagi kepada pihak luar yang membutuhkan. Terdapat beberapa cara untuk mengimplementasikan inisiatif CSR seperti cause-related marketing, phylanthropy, atau green product. CSR dapat menurunkan sikap skeptis konsumen terhadap perusahaan dan meningkatkan sikap positif dan pada akhirnya dapat mempengaruhi niat membeli (Szykman et al., 1997).

CSR sebagai strategi perusahaan tentu diharapkan akan membawa dampak positif pada pemasaran (marketing outcome). Green \& Peloza (2011) menunjukkan bahwa CSR berpengaruh terhadap loyalitas. Penelitian yang dilakukan di negara-negara maju seperti di Amerika Serikat maupun Eropa menemukan bahwa perusahaan yang melaksanakan tanggung jawab sosialnya berhasil membuat pelanggan mereka menjadi loyal. 
Berkaitan dengan perilaku pembelian konsumen, ada beberapa faktor yang mempengaruhi konsumen dalam membeli suatu produk, antara lain faktor eksternal dan faktor internal konsumen ataupun strategi pemasaran perusahaan (Schifman \& Kanuk, 2007; Kotler \& Keller, 2012). Faktor eksternal konsumen antara lain meliputi budaya, kelompok referensi, dan strategi pemasaran perusahaan. Faktor internal konsumen antara lain meliputi persepsi, proses pembelajaran, dan sikap konsumen. Pemahaman mengenai tahapan keputusan yang dilalui konsumen ini penting dalam penyusunan strategi pemasaran termasuk strategy corporate social responsibility.

Terdapat beberapa bentuk program CSR yang dapat diimplementasikan oleh perusahaan seperti cause promotion, cause-related marketing (CRM), corporate social marketing, corporate philanthropy, corporate volunteering dan socially responsible business (Kotler \& Nancy, 2005). Pada cause promotion, perusahaan menggunakan isu tertentu untuk mendapatkan atau meningkatkan perhatian (awareness) dari konsumen. Isu yang digunakan oleh perusahaan tidak harus sesuai dengan bidang bisnis yang dilakukan oleh perusahaan, disini perusahaan berusaha mengajak konsumen (masyarakat) untuk meluangkan waktu atau dana mereka untuk membantu suatu permasalahan yang terjadi.

Dalam CRM, perusahaan akan mengajak konsumen (masyarakat) untuk menggunakan atau membeli produk dari perusahaan, yang nantinya sebagian dari keuntungan hasil penjualan produk tersebut akan disumbangkan pada instansi tertentu atau untuk mengatasi dan mencegah suatu masalah tertentu di masyarakat. Corporate social marketing merupakan kegiatan dimana perusahaan berusaha untuk merubah kebiasaan-kebiasaan di masyarakat (yang kurang baik) dalam suatu isu tertentu, misalnya isu kesehatan seperti bahaya kanker akibat kebiasaan-kebiasaan tidak sehat (merokok, dsb.), atau isu di bidang lingkungan hidup dan juga di bidang sosial dan kemanusiaan. Pada program CSR yang berbentuk corporate philanthropy ini, perusahaan memberikan sejumlah bantuan dalam bentuk dana, jasa atau barang pada pihak-pihak lain yang membutuhkan, baik itu perorangan, lembaga atau organisasi tertentu. Pada community volunteering, perusahaan berusaha mengajak segala elemen di dalam perusahaan (karyawan) untuk turut serta berpartisipasi pada kegiatan corporate social responsibility yang sedang dijalankan oleh perusahaan. Dalam socially responsible business, perusahaan melakukan perbaikan dalam sistem kerja maupun supply chain miliknya dengan tujuan mengurangi dampak negatif terhadap masyarakat dan lingkungan.

Program CSR sudah mulai bermunculan di Indonesia seiring telah disahkannya Undang-Undang Nomor 40 Tahun 2007 tentang Perseroan Terbatas dan Undang-Undang Nomor 25 Tahun 2007 tentang Penanaman Modal. Adapun isi undang-undang tersebut yang berkaitan dengan CSR, yaitu: Pada pasal 74 di Undang-Undang Nomor 40 Tahun 2007, berbunyi: 1) Perseroan yang menjalankan kegiatan usahanya di bidang dan/atau berkaitan dengan sumber daya alam wajib melaksanakan Tanggung Jawab Sosial dan Lingkungan; 2) Tanggung Jawab Sosial dan Lingkungan sebagaimana dimaksud pada ayat (1) merupakan kewajiban Perseroan yang dianggarkan dan diperhitungkan sebagai biaya Perseroan yang pelaksanaannya dilakukan dengan memperhatikan kepatutan dan kewajaran; 3) Perseroan yang tidak melaksanakan kewajiban sebagaimana dimaksud pada ayat (1) dikenai sanksi sesuai dengan ketentuan peraturan perundang-undangan. Sedangkan pada pasal 25 (b) Undang-Undang Penanaman Modal menyatakan kepada setiap penanam modal wajib melaksanakan tanggung jawab sosial perusahaan. Dari kedua pasal diatas dapat kita lihat bagaimana pemerintah Indonesia berusaha untuk mengatur kewajiban pelaksanaan CSR oleh perusahaan atau penanam modal 
Program CSR merupakan investasi bagi perusahaan demi pertumbuhan dan keberlanjutan (sustainability) perusahaan dan bukan lagi dilihat sebagai sarana biaya (cost centre) melainkan sebagai sarana meraih keuntungan (profit centre). Program CSR merupakan komitmen perusahaan untuk mendukung terciptanya pembangunan berkelanjutan (sustainable development). Di sisi lain masyarakat mempertanyakan apakah perusahaan yang berorientasi pada usaha memaksimalisasi keuntungan-keuntungan ekonomis memiliki komitmen moral untuk mendistribusi keuntungan-keuntungannya membangun masyarakat lokal, karena seiring waktu masyarakat tak sekedar menuntut perusahaan untuk menyediakan barang dan jasa yang diperlukan, namun juga menuntut untuk bertanggung jawab sosial.

Penerapan program CSR juga merupakan salah satu bentuk implementasi dari konsep tata kelola perusahaan yang baik (good coporate governance). Diperlukan tata kelola perusahaan yang baik agar perilaku pelaku bisnis mempunyai arahan yang bisa dirujuk dengan mengatur hubungan seluruh kepentingan pemangku kepentingan (stakeholders) yang dapat dipenuhi secara proporsional, mencegah kesalahan-kesalahan signifikan dalam strategi korporasi dan memastikan kesalahan-kesalahan yang terjadi dapat diperbaiki dengan segera.

Keputusan manajemen perusahaan untuk melaksanakan program-program CSR secara berkelanjutan pada dasarnya merupakan keputusan yang rasional. Sebab implementasi program-program CSR akan menimbulkan efek lingkaran emas yang akan dinikmati oleh perusahaan dan seluruh stakeholder-nya. Melalui CSR, kesejahteraan dan kehidupan sosial ekonomi masyarakat lokal maupun masyarakat luas akan lebih terjamin. Kondisi ini pada gilirannya akan menjamin kelancaran seluruh proses atau aktivitas produksi perusahaan serta pemasaran hasil-hasil produksi perusahaan. Sedangkan terjaganya kelestarian lingkungan dan alam selain menjamin kelancaran proses produksi juga menjamin ketersediaan pasokan bahan baku produksi yang diambil dari alam.

Bila CSR benar-benar dijalankan secara efektif maka dapat memperkuat atau meningkatkan akumulasi modal sosial dalam rangka meningkatkan kesejahteraan masyarakat. Modal sosial, termasuk elemen-elemennya seperti kepercayaan, kohesifitas, altruisme, gotong royong, jaringan dan kolaborasi sosial memiliki pengaruh yang besar terhadap pertumbuhan ekonomi. Melalui beragam mekanismenya, modal sosial dapat meningkatkan rasa tanggung jawab terhadap kepentingan publik, meluasnya partisipasi dalam proses demokrasi, menguatnya keserasian masyarakat dan menurunnya tingkat kekerasan dan kejahatan.

Tanggung jawab perusahaan terhadap kepentingan publik dapat diwujudkan melalui pelaksanaan program-program CSR yang berkelanjutan dan menyentuh langsung aspekaspek kehidupan masyarakat. Dengan demikian realisasi program-program CSR merupakan sumbangan perusahaan secara tidak langsung terhadap penguatan modal sosial secara keseluruhan. Berbeda halnya dengan modal finansial yang dapat dihitung nilainya kuantitatif, maka modal sosial tidak dapat dihitung nilainya secara pasti. Namun demikian, dapat ditegaskan bahwa pengeluaran biaya untuk program-program CSR merupakan investasi perusahaan untuk memupuk modal sosial.

\section{Perilaku Pembelian Konsumen}

Banyak tahapan yang dilalui konsumen dalam keputusan pembelian yaitu tahap pengenalan masalah, mengumpulkan informasi, mengevaluasi alternatif, memilih alternatif dan yang terakhir post consumption (Kotler \& Keller, 2012). Post consumption ini penting bagi manajer karena terkait dengan respon konsumen untuk pembelian ulang produk yang ditawarkan. Perusahaan harus memahami tahapan keputusan pembelian tersebut. Tahapan 
pembelian tersebut tidak baku untuk setiap proses namun tergantung pada jenis produk yang akan dibeli maupun banyak tidaknya pertimbangan yang diperlukan dalam proses pengambilan keputusan pembelian (high involvement/low involvement product).

Tujuan utama pemasar adalah melayani dan memuaskan kebutuhan dan keinginan konsumen. Oleh karena itu, pemasar perlu bagaimana memahami bagaimana konsumen berperilaku dalam usaha memuaskan kebutuhan dan keinginannya. Perilaku konsumen merupakan serangkaian aktivitas konsumen dalam mengkonsumsi suatu produk meliputi proses menyeleksi, membeli dan mempergunakan barang dan jasa sehingga memuaskan kebutuhan dan hasratnya. Beberapa aktivitas melibatkan mental dan proses emosional, sebagai tambahan dalam reaksi fisik. Perilaku konsumen berkaitan erat dengan proses pengambilan keputusan dalam usaha memperoleh dan menggunakan barang dan jasa untuk memenuhi kebutuhannya. Perilaku konsumen dipengaruhi oleh faktor-faktor eksternal seperti fakotr budaya dan sosial maupun faktor-faktor internal seperti faktor personal dan psikologis. Secara lebih rinci, yang termasuk dalam dalam faktor-faktor eksternal adalah faktor sosial budaya, faktor ekonomi, faktor teknologi, faktor politik, dan strategi bauran pemasaran (marketing mix) yang dilakukan oleh suatu perusahaan. Sedangkan yang tergolong faktor internal secara lebih rinci meliputi faktor-faktor dari dalam diri konsumen sendiri seperti kebutuhan, motivasi, persepsi, sikap, dan kepribadian terhadap suatu jenis produk atau jasa.

Secara sederhana pengambilan keputusan konsumen terdiri dari tiga komponen utama, yaitu: input, proses dan output (Shiffman \& Kanuk, 2007:443). Input adalah pengaruh eksternal yang dapat berupa informasi mengenai suatu produk dan pengaruhnya terhadap nilai, sikap dan perilaku konsumen. Proses menjelaskan bagaimana konsumen membuat keputusan. Proses tersebut terdiri dari tiga tahap, yaitu pengenalan kebutuhan(need recognition), pencarian sebelum pembelian (prepurchase search) dan evaluasi alternatif (evaluation of alternatives). Tahap pengenalan kebutuhan dimulai dengan adanya motif yang menimbulkan ketegangan dalam diri. Pada tahap pencarian sebelum pembelian, konsumen merasakan adanya kebutuhan yang harus dipuaskan melalui pembelian produk atau jasa. Output dari proses pembelian adalah perilaku membeli dan evaluasi setelah pembelian. Dalam melakukan pembelian ada dua macam, yaitu: trial atau percobaan yakni bila konsumen membeli produk atau merek untuk pertama kalinya. Bila konsumen mendapat kepuasan maka, ia cenderung untuk melakukan pembelian ulang. Evaluasi pembelian berguna untuk mengurangi ketidakpastian konsumen.

Dalam melakukan pembelian, konsumen melewati beberapa tahap, dimulai dengan adanya masalah, kemudian konsumen mencari informasi, menyeleksi alternatif pemecahan masalah, kemudian mengambil keputusan. Pada tahap ini konsumen dipengaruhi oleh adanya motivasi yang merupakan dorongan dalam diri manusia untuk melakukan tindakan dan merupakan kekuatan yang bersifat internal dan eksternal yang mengarahkan perilaku demi pencapaian tujuan. Dasar dari motivasi adalah mencari kesenangan, pemenuhan kebutuhan dasar dan kebutuhan yang lebih tinggi, serta bila kebutuhan telah terpenuhi, konsumen akan mengurangi atau dapat pula meningkatkan tegangan. Tugas pemasar adalah mengenali kebutuhan pasar sasaran dan menciptakan stimulus yang akan memberikan motivasi kepada konsumen agar ia melakukan tindakan untuk memenuhi kebutuhan. Setelah konsumen menyadari adanya masalah, konsumen akan menuju pembelian, untuk itu tahap selanjutnya dari proses pembelian konsumen adalah mencari alternatif pemecahan masalah. Konsumen akan mencari informasi baik secara internal maupun eksternal. Para ahli psikologi menggambarkan proses belajar sebagai proses perubahan pikiran serta perilaku manusia yang bersifat cenderung permanen yang diakibatkan dari pengalaman yang dialaminya. 
Konsumen mendasarkan pilihan yang dipengaruhi oleh sikap yang telah terbentuk, termasuk di dalamnya adalah sikap terhadap merek-merek yang tersedia dalam membuat keputusan pembelian. Sikap adalah kecendrungan yang dipelajari dalam menanggapi suatu obyek secara konsisten, apakah menyukai atau tidak menyukai. Para psikolog dan pemasar berkeyakinan bahwa sikap konsumen merupakan campuran dari kepercayaan, perasaan dan kecenderungan terhadap perilaku. Sikap merupakan hasil proses belajar seseorang. Proses pengolahan informasi akan menimbulkan keinginan untuk membeli walaupun keinginan tersebut belum tentu harus dilaksanakan. Pemasar menggunakan promosi dan strategi harga untuk mempengaruhi konsumen agar membeli produk yang ditawarkannya. Manusia selalu termotivasi untuk berperilaku ke arah pemenuhan kebutuhan dan pemuasan keinginan yang belum terpenuhi. Rasa puas tersebut dapat dirasakan apabila nilai produk melebihi dari apa yang diharapkan konsumen. Apabila konsumen merasa puas dari produk yang dikonsumsinya maka, ia akan melakukan pembelian ulang (repeat purchase). Namun, apabila sebaliknya apabila produk tersebut tidak memberikan kepuasan maka, ia akan berpaling ke produk lain yang memberikan kepuasan lebih dari produk sebelumnya.

Menurut Kotler \& Keller (2012) konsumen akan menjalani sejumlah proses dalam pengambilan keputusan. Berikut ini adalah proses-proses pada saat sebelum dan setelah melakukan pembelian suatu produk, yaitu problem recognition, information source, alternatives evaluation, purchase decision, post-purchase evaluation.

Problem recognition merupakan sebuah proses dimana konsumen akan membeli sebuah produk sebagai solusi terhadap permasalahan yang sedang dihadapinya. Konsumen tidak dapat menentukan produk apa yang akan dibeli, jika tidak ada pengenalan masalah yang muncul. Information source merupakan sebuah proses lanjutan dari pengenalan masalah dimana konsumen akan termotivasi untuk mencari informasi dalam menyelesaikan permasalahan yang sedang dihadapinya. Proses pencarian informasi tersebut dapat berasal dari dalam memori (internal) maupun berdasarkan pengalaman orang lain (eksternal). Alternative evaluation merupakan sebuah proses lanjutan dari pencarian informasi, dimana setelah konsumen tersebut mendapatkan berbagai macam informasi konsumen tersebut akan mengevaluasi alternatif-alternatif strategis apa saja yang akan dipilih untuk mengatasi permasalahan yang dihadapinya. Purchase decision merupakan sebuah proses lanjutan dari evaluasi alternatif dimana konsumen akan membuat keputusan pembelian suatu produk yang diinginkan. Terkadang konsumen memerlukan waktu yang cukup lama sebelum konsumen tersebut memutuskan untuk membeli produk yang diinginkan, karena adanya hal-hal yang masih perlu dipertimbangkan. Post-purchase evaluation merupakan sebuah proses setelah konsumen membeli suatu produk dimana konsumen akan mengevaluasi apakah produk tersebut sesuai dengan keinginannya. Didalam proses ini, dapat terjadi kepuasan dan ketidakpuasan konsumen. Konsumen akan merasa puas jika produk yang telah dibeli sesuai dengan keinginannya dan selanjutnya akan meningkatkan permintaan terhadap merek produk tersebut pada masa yang akan datang. Tetapi sebaliknya, konsumen akan merasa tidak puas jika barang yang telah dibeli tidak sesuai dengan keinginannya dan hal ini akan menurunkan permintaan konsumen pada masa yang akan datang.

\section{METODE PENELITIAN}

\section{Desain Penelitian}

Penelitian ini merupakan penelitian dasar yang bertujuan untuk mengembangkan teori dengan menjelaskan hubungan antar variabel. Penelitian ini dilakukan dengan pendekatan kualitatif yakni in-depth interview mengenai faktor-faktor yang mempengaruhi konsumen 
dalam pembelian green product, bagaimana proses pembelian konsumen dalam green product, serta respon konsumen.

Penelitian ini ingin mengeksplorasi dan menginvestigasi perilaku konsumen dengan menggunakan grounded theory. Grounded theory adalah proses investigasi secara induktif dimana peneliti merumuskan sebuah teori tentang fenomena dengan mengumpulkan dan menganalisis data yang relevan secara sistematis. Grounded theory menurut Goulding (2003) merupakan metode dimana teori didasarkan pada perkataan dan tindakan individual dalam suatu penelitian, metode ini cocok untuk mempelajari tindakan individu yang memiliki elemen interaksi dalam tindakannya. Pengembangan teori merupakan tujuan dari peneliti sesuai dengan relevansi yang muncul dari data. Keuntungan dari penggunaan metode ini adalah peneliti dapat melihat permasalahan melebihi apa yang terlihat di permukaan, memungkinkan intrepretasi sebelum mengembangkan konsep terakhir, dan dapat menunjukkan penjelasan dengan data pendukung. Penelitian bertujuan mengeksplorasi dan mengidentifikasi bagaimana strategi green marketing yang merupakan salah satu bentuk CSR yang dilakukan oleh perusahaan akan mempengaruhi proses keputusan pembelian dan respon konsumen terkait produk yang ramah lingkungan.

\section{Sumber dan Teknik Pengambilan Data}

Jenis data yang digunakan dalam penelitian ini adalah data primer yang didapat langsung dari hasil wawancara responden. Data sekunder yang digunakan dalam penelitian ini diperoleh dari sumber eksternal seperti media, buku, dan literatur lainya.

Penelitian ini menggunakan non probabilty sampling dengan sumber data dipilih secara accidental sampling yang mana partisipan dipilih secara kebetulan kepada konsumen yang menggunakan produk ramah lingkungan atau produk yang diproduksi oleh perusahaan yang melakukan kegiatan corporate social responsibility yang secara kebetulan ditemui dan bersedia untuk dijadikan partisipan

In-depth interview pada responden terpilih dipilih sebagai teknik wawancara yang dipilih. Burns \& Bush (2010) menjelaskan bahwa teknik ini merupakan satu rangkaian penyelidik yang diajukan satu persatu kepada responden dengan pewawancara langsung untuk mendapatkan ide dari apa yang dipikirkan oleh subyek tentang sesuatu atau kenapa subyek melakukan suatu hal dengan cara tertentu. Teknik ini dilakukan secara intens langsung face to face dan mendalam untuk menghasilkan informasi yang berkualitas. Dalam penelitian ini digunakan semi-structured in-depth interview dalam pengambilan data karena dengan demikian wawancara dapat dilakukan secara lebih fleksibel dan data yang tidak tampak bisa diobservasi. Pengambilan data dilakukan terus menerus sampai peneliti mencapai theoretical saturation, yakni pada saat tidak ada data tambahan yang dapat ditemukan yang akan ditambahkan kedalam kategori yang dikembangkan dan diuji maka pengambilan data kemudian dihentikan (Pace, 2003).

Jarratt (1996) menyatakan bahwa keuntungan dari menggunakan teknik semistructured in-depth interview antara lain peneliti dapat menyelidiki, menanyakan banyak pertanyaan tambahan, dan menggali sedalam mungkin subyek sehingga informasi yang didapat sangat kaya, dalam dan mengandung banyak informasi. Kelemahanya teknik ini kurang terstruktur sehingga respon yang didapat bisa sangat bermacam macam. Untuk itu peneliti membutuhkan guideline pertanyaan untuk memfokuskan interview dengan responden. 
Lilik Rudianto

\section{Variabel penelitian}

Variabel yang digunakan dalam penelitian ini adalah aktivitas corporate social responsibility, proses keputusan pembelian, dan respon konsumen. Agar tidak terjadi kesalahpahaman dalam mendefinisikan variabel yang digunakan dalam penelitian ini maka variabel penelitian tersebut didefinisikan sebagai berikut :

1. Aktivitas Corporate Social Responsibility adalah aktivitas yang dilakukan perusahaan yang terkait dengan kegiatan kegiatan yang relevan dengan masalah lingkungan sosial maupun lingkungan alam.

2. Proses Keputusan Pembelian adalah tahapan yang dilalui konsumen dalam memutuskan penggunaan suatu produk. Tahapan tersebut meliputi a) identifikasi kebutuhan, b) pencarian informasi untuk memenuhi kebutuhan tersebut, c) evaluasi berbagai alternatif yang memungkinkan, d) pemilihan alternatif/keputusan pembelian, e) post consumption.

3. Respon Konsumen adalah tanggapan konsumen atas aktivitas-aktivitas yang dilakukan perusahaan terkait kegiatan corporate social responsibility. Respon bisa berupa kognitif, afektif, konatif, dan perilaku.

\section{Uji Validitas dan Reliabilitas}

Uji reliabilitas berhubungan dengan seberapa konsisten peneliti dalam melakukan penelitian dengan menggunakan teknik yang diulang-ulang pada obyek yang sama akan memberikan hasil yang sama (Gremler, 2004). Untuk mendapatkan data yang andal tergantung pada kemampuan penilai atau pemberi kode untuk tetap konsisten mengklasifikasikan data pada spesifik kategori, dimana diskusi penilai ini terjadi antara intrajudge reliability dan interjudge reliability. Intrajudge reliability merupakan seberapa konsisten seorang penilai membuat keputusan kategori selama penelitian sedangkan interjudge reliability merupakan tingkatan dimana dua atau lebih penilai setuju bahwa observasi harus diklasifikasikan dengan cara tertentu.

Validitas data dalam pendekatan kualitatif didapat dari cara triangulasi (Creswell \& Miller, 2000; Guion, Diehl, \& McDonald, 2011) dengan mengkombinasi sumber data yang berbeda untuk melihat data. Triangulasi dilakukan dengan melakukan cek silang data kepada sumber yang berbeda. Dalam penelitian ini data diperoleh dengan wawancara pada konsumen lalu dicek dengan sumber pada akademisi dan sumber media.

\section{HASIL DAN PEMBAHASAN}

\section{Deskripsi Hasil Penelitian}

Penelitian ini berfokus membahas tentang bagaimana perilaku pembelian konsumen khususnya produk yang diproduksi oleh perusahaan yang melakukan kegiatan CSR, dan bagaimana respon konsumen terhadap aktivitas CSR yang dilakukan perusahaan. Data didapatkan oleh peneliti dengan melakukan wawancara kepada 14 orang dengan durasi masing-masing sekitar 45 menit wawancara. Adapun karakteristik demografi dari informan adalah sebagai berikut.

Tabel 1

Karakteristik Informan Penelitian

\begin{tabular}{|l|l|l|l|l|}
\hline Informan & Umur & Pekerjaan & Pendidikan & Produk yang dibeli \\
\hline 1 & 29 & $\begin{array}{l}\text { Karyawan Bank } \\
\text { Niaga }\end{array}$ & $\begin{array}{l}\text { Sarjana Teknik } \\
\text { Lingkungan }\end{array}$ & The Bodyshop \\
\hline 2 & 47 & Karyawan Hotel & SMA & Lampu Philips \\
\hline
\end{tabular}




\begin{tabular}{|l|l|l|l|l|}
\hline & & Garden & & \\
\hline 3 & 36 & Karyawan Carefour & D3 Ekonomi & Batik Mangrove, The Bodyshop \\
\hline 4 & 48 & Ibu rumah tangga & Sarjana & Lampu philips, sayuran organik \\
\hline 5 & 27 & $\begin{array}{l}\text { Karyawan Bank } \\
\text { Bukopin }\end{array}$ & Sarjana Psikologi & $\begin{array}{l}\text { Tas dari eceng gondok, batik } \\
\text { pewarna alami }\end{array}$ \\
\hline 6 & 47 & Wiraswasta & Sarjana ekonomi & AC low watt \\
\hline 7 & 47 & Dosen unesa & S3 & AC low watt, lampu Philips \\
\hline 8 & 38 & $\begin{array}{l}\text { Karyawan swasta } \\
\text { (Teh Botol Sosro) }\end{array}$ & Sarjana ekonomi & AC low watt \\
\hline 9 & 18 & Mahasiswa & SMA & $\begin{array}{l}\text { Gelas daur ulang, sabun mandi } \\
\text { eco green }\end{array}$ \\
\hline 10 & 38 & Guru SMA & Sarjana & AC low watt \\
\hline 11. & 29 & Wiraswasta & Sarjana ekonomi & AC low watt, lampu Philips \\
\hline 12 & 31 & $\begin{array}{l}\text { Karyawan swasta } \\
\text { (Granito) }\end{array}$ & Sarjana teknik & Produk The Bodyshop \\
\hline 13 & 38 & Wiraswasta & Sarjana teknik & Sabun mandi \\
\hline 14 & 32 & Karyawan swasta & Sarjana & Pemanas surya \\
\hline
\end{tabular}

Peneliti kemudian menganalisis hasil wawancara dengan menemukan pola dari transkip hasil wawancara dan merumuskannya dalam laporan. Mengadopsi pendapat Gremler (2008), uji reliabilitas dilakukan dengan berfokus pada interjudge reliability, yaitu sejauh mana satu atau dua juri setuju dengan cara peneliti mengklasifikasikan dan memberi kode dengan cara tertentu. Satu juri didatangkan dan menyaksikan peneliti melakukan coding.

Uji validitas dalam penelitian ini mengadopsi pendapat Shah \& Corley (2006) yaitu memperpanjang waktu observasi, triangulasi sumber data, dan hasil wawancara diteliti oleh subyek. Dalam penelitian ini validasi dicapai dengan triangulasi berupa pengumpulan data yang lebih dari satu sumber, wawancara dilakukan terus menerus dan berhenti ketika data yang didapat secara garis besar sudah sama. Data yang didapat juga diperkuat dengan peer debriefing yaitu dengan membicarakan masalah penelitian dengan tanya jawab kepada teman sejawat yang cukup mengerti dengan permasalahan penelitian. Setelah data terkumpul dan sudah melalui uji reliabilitas dan validitas ringkasan hasil wawancara terangkum dalam tabel berikut

Tabel 2

\section{Ringkasan Hasil Wawancara}

\begin{tabular}{|l|l|l|l|}
\hline Tema & Pertanyaan & Kategori & Frek. \\
\hline $\begin{array}{l}\text { Karakteristik } \\
\text { responden } \\
\text { terkait } \\
\text { lingkungan }\end{array}$ & $\begin{array}{l}\text { Bagaimana kepedulian } \\
\text { anda pada sesama }\end{array}$ & $\begin{array}{l}\text { Orang seharusnya membantu orang lain } \\
\text { yang kurang beruntung }\end{array}$ & 6 \\
\cline { 3 - 4 } & $\begin{array}{l}\text { Menolong orang yang dalam kesulitan } \\
\text { adalah sangat penting }\end{array}$ & 4 \\
\cline { 2 - 4 } & $\begin{array}{l}\text { Bagaimana kepedulian } \\
\text { anda pada lingkungan } \\
\text { alam }\end{array}$ & $\begin{array}{l}\text { Saya tidak khawatir kondisi lingkungan di } \\
\text { masa depan, generasi yang akan mampu } \\
\text { menjaganya dengan baik }\end{array}$ & 5 \\
\cline { 2 - 4 } & $\begin{array}{l}\text { Bagaimana sikap anda } \\
\text { pada keadilan }\end{array}$ & $\begin{array}{l}\text { Orang butuh menjaga diri sendiri, tanpa } \\
\text { perlu mengkhawatirkan orang lain }\end{array}$ & 5 \\
\cline { 3 - 4 } & $\begin{array}{l}\text { Setiap orang di dunia harus diperlakukan } \\
\text { sama }\end{array}$ & 6 \\
\cline { 3 - 4 } & $\begin{array}{l}\text { Setiap orang harus tinggal di lingkungan } \\
\text { yang aman }\end{array}$ & 5 \\
\hline
\end{tabular}


Lilik Rudianto

\begin{tabular}{|c|c|c|c|}
\hline \multirow[t]{5}{*}{$\begin{array}{l}\text { Pemahaman } \\
\text { CSR }\end{array}$} & \multirow[t]{5}{*}{$\begin{array}{l}\text { Apa yang anda fahami } \\
\text { tentang CSR }\end{array}$} & $\begin{array}{l}\text { Perusahaan memproduksi produk tidak } \\
\text { berbahaya }\end{array}$ & 10 \\
\hline & & Perusahaan mengelola limbahnya & 6 \\
\hline & & $\begin{array}{l}\text { Perusahaan ikut membantu masalah } \\
\text { masyarakat }\end{array}$ & 6 \\
\hline & & Perusahaan menjaga lingkungan alam & 9 \\
\hline & & Perusahaan menggunakan bahan dari alam & 9 \\
\hline & \multirow{4}{*}{$\begin{array}{l}\text { Alasan perusahaan } \\
\text { melakukan CSR }\end{array}$} & Bentuk promosi yang baru & 1 \\
\hline & & Bentuk promosi terselubung & 4 \\
\hline & & $\begin{array}{l}\text { Kewajiban perusahaan untuk menutupi rasa } \\
\text { bersalahnya }\end{array}$ & 1 \\
\hline & & Untuk menarik simpati masyarakat & 1 \\
\hline \multirow[t]{7}{*}{ Ide CSR } & \multirow{7}{*}{$\begin{array}{l}\text { Bentuk - bentuk CSR } \\
\text { bagaimana yang } \\
\text { diharapkan/dipandang } \\
\text { positif konsumen }\end{array}$} & Membuka lapangan pekerjaan baru & 3 \\
\hline & & $\begin{array}{l}\text { Memberikan fasilitas/kegiatan untuk } \\
\text { masyarakat }\end{array}$ & 7 \\
\hline & & Memberi beasiswa & 8 \\
\hline & & Menjaga kelestarian alam & 6 \\
\hline & & Membuat barang yang berkualitas & 10 \\
\hline & & $\begin{array}{l}\text { Membuat barang yang ramah } \\
\text { lingkungan/tidak bahaya }\end{array}$ & 4 \\
\hline & & Membantu orang miskin & 2 \\
\hline \multirow{20}{*}{$\begin{array}{l}\text { Proses } \\
\text { Keputusan } \\
\text { Pembelian }\end{array}$} & \multirow{7}{*}{$\begin{array}{l}\text { Kebutuhan apa yang } \\
\text { membuat anda membeli } \\
\text { Produk tersebut }\end{array}$} & Barangnya berkualitas & 9 \\
\hline & & Efisiensi biaya operasional & 4 \\
\hline & & Barangnya unik & 3 \\
\hline & & Ikut menjaga lingkungan & 5 \\
\hline & & Dihargai teman-teman & 3 \\
\hline & & Menjadi konsumen yang cerdas & 3 \\
\hline & & Barang yang aman/tidak bahaya & 2 \\
\hline & \multirow{4}{*}{$\begin{array}{l}\text { Bagaimana anda } \\
\text { mendapatkan informasi } \\
\text { ttg produk dan kegiatan } \\
\text { CSR perusahaan }\end{array}$} & Aktif mencari informasi & 10 \\
\hline & & Sumber informasi media & 7 \\
\hline & & Sumber informasi teman & 2 \\
\hline & & Sumber informasi brosur dari perusahaan & 2 \\
\hline & \multirow[t]{5}{*}{ Evaluasi alternatif } & Dasar evaluasi adalah dana & 7 \\
\hline & & Dasar evaluasi kualitas barang & 8 \\
\hline & & Dasar evaluasi adalah manfaat & 7 \\
\hline & & Dasar evaluasi adalah pendapat teman & 5 \\
\hline & & $\begin{array}{l}\text { Dasar evaluasi adalah keterlibatan perasaan } \\
\text { bangga/senang }\end{array}$ & 2 \\
\hline & \multirow{4}{*}{$\begin{array}{l}\text { Bagaimana evaluasi } \\
\text { setelah konsumsi }\end{array}$} & Akan rekomendasi ke teman teman & 7 \\
\hline & & Akan membeli lagi & 5 \\
\hline & & Puas, telah melakukan pilihan dgn benar & 5 \\
\hline & & Kecewa, barang terlalu mahal & 2 \\
\hline \multirow{6}{*}{$\begin{array}{l}\text { Respon atas } \\
\text { CSR aktivity } \\
\text { dan green } \\
\text { product }\end{array}$} & \multirow{6}{*}{$\begin{array}{l}\text { Bagaimana respon } \\
\text { terhadap CSR aktivity } \\
\text { yang dilakukan } \\
\text { perusahaan }\end{array}$} & Curiga harga barang dinaikkan & 7 \\
\hline & & Curiga itu hanya kebohongan publik & 6 \\
\hline & & Tidak sebesar yang diberitakan & 7 \\
\hline & & Suka pada aktivitas CSR & 2 \\
\hline & & $\begin{array}{l}\text { Membeli produk yang melakukan aktivitas } \\
\text { CSR sama artinya ikut melakukan kegiatan } \\
\text { CSR }\end{array}$ & 3 \\
\hline & & $\begin{array}{l}\text { Perusahaan yang melakukan aktivitas CSR } \\
\text { adalah perusahaan besar/bereputasi baik }\end{array}$ & 2 \\
\hline
\end{tabular}




\begin{tabular}{|l|l|l|l|}
\hline \multirow{2}{*}{$\begin{array}{l}\text { Bagaimana respon } \\
\text { terhadap keberadaan } \\
\text { green product }\end{array}$} & Produk bermanfaat bagi lingkungan & 8 \\
\cline { 3 - 3 } & Produk bermanfaat bagi diri sendiri & 11 \\
\cline { 3 - 4 } & $\begin{array}{l}\text { Suka mengkonsumsi karena merasa menjadi } \\
\text { konsumen yang cerdas }\end{array}$ & 2 \\
\cline { 2 - 3 } & $\begin{array}{l}\text { Suka mengkonsumsi karena menjadi orang } \\
\text { yang peduli lingkungan }\end{array}$ & 3 \\
\hline
\end{tabular}

\section{Diskusi}

Penelitian ini berfokus pada penemuan pola tentang bagaimana perilaku pembelian konsumen terkait produk yang dihasilkan perusahaan yang melakukan aktivitas CSR. Berikut adalah proposisi sebagai hasil intrepretasi peneliti.

Hasil penelitian menunjukkan bahwa informan melakukan CSR sebagai "bentuk promosi yang terselubung", "aktivitas untuk menarik simpati masyarakat", "bentuk promosi baru" atau merupakan "kewajiban perusahaan untuk menutupi rasa bersalahnya". Namun ada pula informan yang menyatakan bahwa CSR merupakan tanggung jawab perusahaan "menjaga lingkungan" atau sebagai salah satu bentuk kebaikhatian membantu masyarakat. Sedangkan di Indonesia terdapat aturan yang mewajibkan perusahaan untuk melakukan aktivitas CSR. Demikan pula dengan informan akademisi yang menyatakan bahwa alasan utama perusahaan melakukan aktivitas CSR adalah keberadaan undang-undang dan keinginan perusahaan untuk menjaga image perusahaan dalam masyarakat. Dengan demikian disusun proposisi 1: Persepsi konsumen tentang tujuan aktivitas CSR mempengaruhi evaluasi konsumen tentang kegiatan CSR tersebut.

Dalam penelitian ini semua informan adalah para konsumen produk ramah lingkungan atau produk dari perusahaan yang melaksanakan kegiatan CSR. Hasil penelitian menunjukkan bahwa para informan tersebut telah memiliki pemahaman yang baik mengenai konsep CSR, bahwa CSR merupakan "aktivitas perusahaan dengan memproduksi produk tidak berbahaya", "perusahaan mengelola limbahnya", "perusahaan ikut membantu masalah masyarakat" atau "perusahaan menjaga lingkungan alam". Terkait dengan hal tersebut Kotler \& Keller (2012) menyatakan salah satu dari empat komponen yang menjadi karakteristik pemasaran holistik adalah pemasaran kinerja (performance marketing). Di dalam pemasaran kinerja (performance marketing) dapat dilihat bahwa hasil yang diperoleh perusahaan tidak hanya berasal dari program dan aktivitas pemasaran yang mereka lakukan, namun juga sebagai hasil dari perusahaan yang memberikan perhatiannya pada kegiatan-kegiatan terkait dengan kepatuhan mereka terhadap hukum, etika dan kepedulian terhadap masyarakat dan lingkungan. Lee \& Shin (2010) ini menunjukkan bahwa terdapat hubungan yang positif antara kesadaran konsumen akan aktivitas CSR terhadap minat pembelian (purchase intention). Berdasar uraian di atas disusunlah proposisi 2: Evaluasi konsumen atas aktifitas CSR yang dilakukan perusahaan mempengaruhi keputusan pembelian

Hasil penelitian ini menunjukkan bahwa beberapa informan menyatakan alasan pembelian produk ramah lingkungan dengan alasan ekonomis, antara lain: "efisiensi biaya operasional" atau "barangnya berkualitas". Alasan kedua adalah alasan emosional, seperti dinyatakan oleh informan "merasa menjadi konsumen yang cerdas" atau "merasa ikut menjaga lingkungan alam". Selain itu terdapat pula alasan sosial seperti "dihargai temanteman" atau "barangnya unik". Dan alasan terakhir adalah alasan fungsioanal, yaitu mendapatkan "barang yang aman/tidak berbahaya". Menurut Ali et al. (2010), aktivitas CSR secara potensial dapat menciptakan nilai tambah bagi perusahaan karena CSR mengkombinasikan aspek sosial dan lingkungan dalam menjalankan bisnisnya. Jika dikelola dengan baik, pendekatan CSR dapat menciptakan nilai bagi dua pihak, yaitu bisnis itu sendiri 
dan masyarakat secara simultan. Menurut Green \& Peloza (2011) yang penting untuk diperhatikan oleh manajer adalah kemampuan untuk membedakan nilai CSR yang akan diterjemahkan dalam pengaruh yang berbeda pada isu sosial dan lingkungan. Ketika seorang pelanggan memilih produk yang mengandung CSR dalam bentuk nilai fungsional, tersebarnya produk secara luas di antara ribuan atau jutaan konsumen akan memberikan dampak yang lebih besar kepada masyarakat. Ketika CSR ditambahkan pada fitur produk, maka konsumen akan selalu mengingat manfaat fungsional CSR yang menciptakan tingkat kesadaran dan keterlibatan yang lebih tinggi akan akibat dari konsumsi. Dapat disusun proposisi 3: Aktivitas CSR berdampak pada nilai yang diterima konsumen, baik nilai ekonomis, nilai fungsional, nilai emosional, maupun nilai sosial.

Hasil penelitian ini menunjukkan bahwa sebagian besar informan menunjukkan kecurigaan terhadap akitivitas CSR yang dilakukan perusahaan. Diantaranya "curiga harga barang dinaikkan", "curiga bahwa aktivitas itu hanya kebohongan publik", dan kegiatan CSR yang diinformasikan "tidak sebesar yang diberitakan". Dalam hal ini Trudel \& Cotte (2009) menemukan bahwa konsumen bervariasi pada keinginan untuk membayar untuk sebuah produk etis dari perusahaan di dasarkan pada ekspektasi mereka terkait dengan perilaku etis dari perusahaan ini. Dengan demikian dapat disusun proposisi 4: Aktivitas CSR membuat konsumen menjadi skeptis pada perusahaan.

Hasil penelitian menunjukkan semua informan merasa bahwa produk yang ramah lingkungan "bermanfaat bagi diri sendiri" karena "barang aman/tidak berbahaya". Lebih lanjut Hasil dari pelaksanaan aktifitas $C S R$ terhadap tanggapan pelanggan meliputi evaluasi yang bersifat positif terhadap perusahaan (Brown \& Dacin, 1997), tingginya niat beli konsumen (Mohr \& Webb, 2005). Dengan demikian dapat disusun proposisi 5: Aktivitas CSR terkait produk yang langsung dapat dirasakan konsumen meningkatkan sikap positif konsumen terhadap produk.

Hasil penelitian menunjukkan informan merasa bahwa perusahaan yang melakukan aktivitas CSR adalah "perusahaan besar atau perusahaan yang bereputasi [baik]". Hellen et al. (2006) mengatakan bahwa aktivitas CSR meningkatkan kredibilitas merek/perusahaan. Corporate social responsibility seringkali digunakan sebagai kriteria penting untuk mengendalikan reputasi perusahaan, dimana reputasi perusahaan juga berhubungan dengan corporate credibility yang dimiliki oleh perusahaan. Ahmad \& Buttle (2001) menyatakan sekarang ini diyakini bahwa menjadi perusahaan yang memiliki tanggungjawab sosial dapat meningkatkan reputasi dan citra yang lebih baik di pasar. Maka disusun proposisi 6: Aktifitas CSR berdampak pada persepsi konsumen atas citra perusahaan dan produk serta meningkatan kredibilitas perusahaan dan merek.

Hasil penelitian menunjukkan bahwa informan dalam mengevaluasi keputusan pembeliannya menyatakan akan "merekomendasikan ke teman", "akan membeli lagi", karena merasa "puas, telah melakukan dengan benar". Namun informan yang berpemahaman negatif terhadap CSR, seperti "[CSR merupakan] bentuk promosi terselubung", "[CSR hanya] untuk menarik simpati masyarakat" membuat konsumen merasa curiga pada aktivitas CSR tersebut sehingga dalam evaluasi atas keputusan pembeliannya, informan merasa kecewa karena "barang terlalu mahal". Aktivitas CSR akan menambah nilai produk yang dirasakan konsumen. Aktivitas CSR ini akan menciptakan loyalitas (Onlaor \& Rotchanakitumnuai, 2010; Zdravkovic et al., 2010; Mohr, Webb, \& Harris, 2001). Dengan demikian disusun proposisi 7: Penilaian konsumen atas aktivitas CSR mempengaruhi loyalitas konsumen.

Hasil penelitian ini menunjukkan bahwa informan memiliki tingkat kepedulian pada lingkungan yang bervariasi. Beberapa informan mengatakan "orang harus diperlakukan sama", namun beberapa orang lagi menyatakan bahwa "orang butuh menjaga diri sendiri 
tanpa perlu mengkhawatirkan orang lain". Sedangkan apabila dilihat dari karakteristik pendidikan informan, hampir semua informan berpendidikan tinggi (Sarjana) dan berada pada usia produktif (29-47 tahun) di mana hampir semuanya adalah karyawan. Menurut informan akademisi, karakteristik konsumen yang mempengaruhi keputusan pembelian produk ramah lingkungan adalah konsumen yang "berusia 30-45 tahun, berpendidikan tinggi, tingkat ekonomi yang cukup". Lebih lanjut informan akademisi tersebut menyatakan bahwa antara karakteristik demografi dengan kepedulian lingkungan ini dapat berinteraksi dalam mempengaruhi keputusan pembelian. Sen \& Bhattacharya (2001) menyatakan bahwa ketika konsumen altruistic mempersepsikan merek yang mencoba untuk memproyeksikan citra CSR dengan mengasosiasikannya melalui suatu social cause, konsumen akan berusaha membuat penilaian pada kredibilitas merek tersebut berdasarkan attribution of motivation, dimana tetap meyakinkan konsumen bahwa brand tersebut sesuai dengan personal identities konsumen dan untuk memuaskan kebutuhan dasar definisi personal. Altruistic value yang ada pada diri konsumen akan mempengaruhi perilaku mereka dalam merespon aktivitas CSR, seperti yang disampaikan oleh Stren, Kalof \& Mohamed (2009). Maka dapat disusun proposisi 8: Karakteristik konsumen (umur, pendidikan, pendapatan dan kepedulian pada lingkungan memperkuat pengaruh CSR terhadap keputusan pembelian konsumen.

Hasil penelitian menunjukkan bahwa sebagian besar informan memiliki budaya kebersamaan, yaitu mereka mengatakan bahwa "setiap orang seharusnya membantu orang lain yang kurang beruntung", atau "adalah sangat penting menolong orang lain yang dalam kesulitan". Rojanasak \& Ken (2009) mengatakan bahwa pengaruh inisiatif CSR terhadap brand preference dipengaruhi oleh nilai budaya. Dengan demikian dapat disusun proposisi 9:

Budaya konsumen yang kolektivism (lebih mengutamakan kebersamaan) mempengaruhi sikap atas kegiatan CSR dan keputusan pembelian produk ramah lingkungan.

Sembilan proposisi tersebut merupakan suatu hubungan kausal antara proposisi satu dengan proposisi lainya. Keterkaitan semua proposisi hasil penelitian satu dengan proposisi lainya dapat dilihat dalam gambar berikut

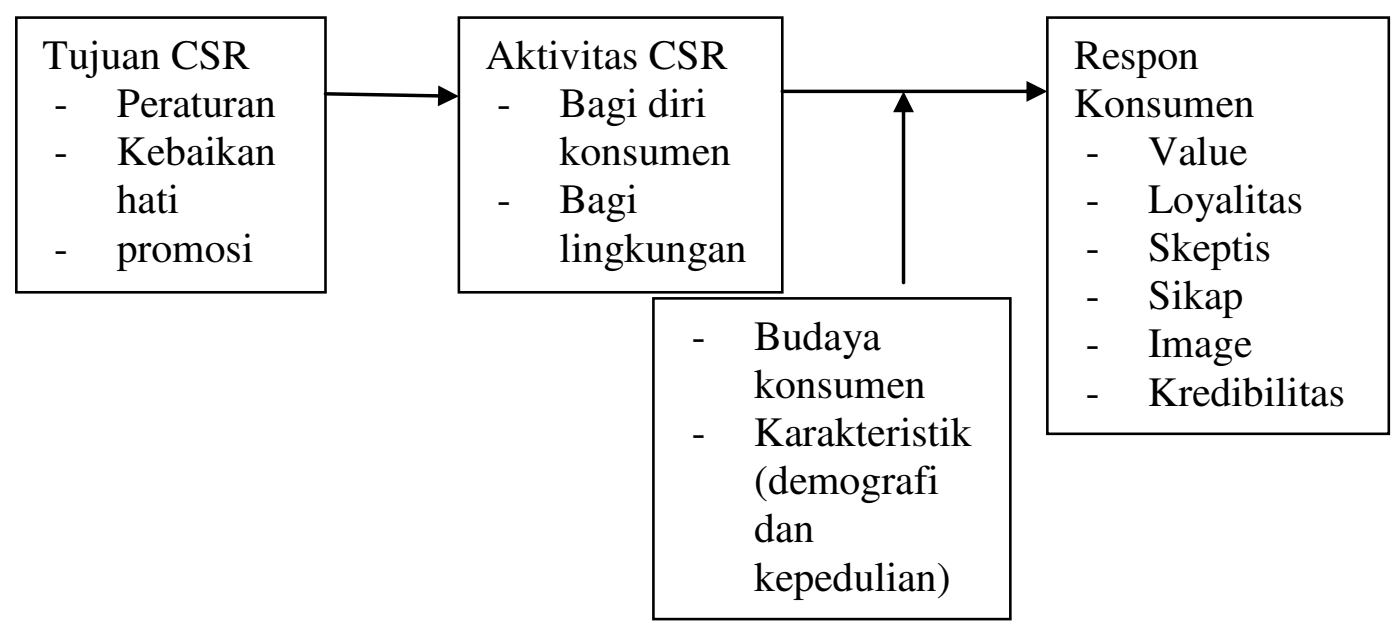

Gambar 1

Model CSR: Variabel Anteseden dan Konsekuensi 


\section{KESIMPULAN DAN SARAN Kesimpulan}

Terdapat 9 proposisi sebagai hasil penelitian ini, yaitu: 1) persepsi konsumen tentang tujuan aktivitas CSR mempengaruhi evaluasi konsumen tentang kegiatan CSR tersebut; 2) evaluasi konsumen atas aktifitas CSR yang dilakukan perusahaan mempengaruhi keputusan pembelian; 3) aktivitas CSR berdampak pada nilai yang diterima konsumen baik nilai ekonomis, nilai fungsional, nilai emosional, maupun nilai sosial; 4) aktivitas CSR membuat konsumen menjadi skeptis pada perusahaan; 5) aktivitas CSR terkait produk yang langsung dapat dirasakan konsumen meningkatkan sikap positif konsumen terhadap produk; 6) aktivitas CSR berdampak pada persepsi konsumen atas citra perusahaan dan produk serta meningkatan kredibilitas perusahaan dan merek; 7) penilaian konsumen atas aktivitas CSR mempengaruhi loyalitas konsumen; 8) karakteristik konsumen (umur, pendidikan, pendapatan dan kepedulian pada lingkungan memperkuat pengaruh CSR terhadap keputusan pembelian konsumen; 9) budaya konsumen yang kolektivism (lebih mengutamakan kebersamaan) mempengaruhi sikap atas kegiatan CSR dan keputusan pembelian produk ramah lingkungan.

Ditemukan variabel moderasi pada hubungan aktivitas CSR dan respon konsumen pada CSR yaitu karakteristik konsumen berupa demografi dan kepedulian pada lingkungan yang pada awalnya dianggap sebagai varienel anteseden. Hasil penelitian kualitatif yang berupa proposisi-proposisi penelitian ini perlu dijabarkan dalam bentuk hipotesis yang nantinya perlu diuji secara kuantitif. Agar hasil penelitian lebih terfokus, maka penelitian lanjutan perlu dilakukan dengan objek penelitian yang spesifik.

\section{DAFTAR REFERENSI}

Ahmad R., Buttle F. 2001. Customer retention: a potentially potent marketing management strategy. Journal of Strategic Marketing, 9 (1), 29-45.

Ali A., Israr A. 2012. Environtment friendly product: factors that influence the green purchase intentions of Pakistani Consumers. Pakistani Journal Technology Science, pp 84-117.

Ali I., Rehman KU., Yilmaz, AK., Nazir S., Ali JF. 2010. Effects of corporate social responsibility on consumer retention in cellular industry of Pakistan. African Journal of Business management, Vol.4(4), pp. 475-485.

Ashok R. 2004. Marketing Strategies: A Contemporary Approach. New Jersey: Prentice Hall.

Becker-Olsen KL., Cudmore BA., Hill, RP. 2006. The impact of Perceived Corporate Social Responsibility on Consumer Behavior. Journal of Business Research, 59, pp. 46-53.

Brown TJ., Dacin PA. 1997. The company and the product: corporate associations and consumer product responses. The Journal of Marketing, 68-84.

Burns AC., Bush RF. 2010. Marketing Research. New Jersey: Prentice Hall.

Creswell JW., Miller DL. 2000. Determining validity in qualitative inquiry. Theory Into Practice, 39 (3), 124-130.

Goulding, C. 2003. Issues in representing the postmodern consumer", Qualitative Market Research: An International Journal, 6 (3), 152-159.

Green T., Peloza J. 2011. How does corporate social responsibility create value for consumers? Journal of Consumer Marketing, 28/1, pp. 48-56.

Gremler DD. 2004. The critical incidence technique in service research. Journal of Service Research, 7 (1), 65-89. 
Lilik Rudianto

Guion LA., Diehl DC., McDonald D. 2011. Triangulation: Establishing the Validity of Qualitative Studies. Working paper: University of Florida.

Jarratt DG. 1996. A comparison of two alternative interviewing techniques used within an integrated research design: a case study in outshopping using semi-structured and nondirected interviewing techniques. Marketing Intelligence \& Planning, 14 (6), 6-15.

Kotler P., Keller KL. 2012. Marketing Management. New Jersey: Prentice Hall.

Kotler P., Nancy L. 2005. Corporate social responsibility: doing the most good for your company and your cause. Resource Policy, 27, 61-75.

Lee, KH., Shin D. 2010. Consumers' responses to CSR activities: The linkage between increased awareness and purchase intention. Public Relation Review, 36, pp. 193-195

Mohr LA., Webb DJ., Harris KE. 2001. Do Consumers expect companies to be socially responsible? The impact of Corporate Social responsibility of buying behavior. Journal of Consumer Affairs, 35, pp. 45-72.

Mohr LA., Webb DJ. 2005. The effects of corporate social responsibility and price on consumer response. Journal of Consumer Affairs, 39, 121-147.

Onlaor W., Rotchanakitumnuai S. 2010. Enhancing Customer Loyalty towards CSR of Thai Mobile Service Provider. World Academy of Science, Engineering and Technology, 66, 1574-1578.

Pace S. 2004. A Grounded Theory of the Flow Experiences of Web Users. International Journal of Human-Computer Studies, 60, 327-363.

Rahim R., Jalaludin F., Tajuddun K. 2011. The Importance Of Corporate Responsibility On Consumer Behaviour In Malaysia. Asian Academy of Management Journal, 16, pp 119139.

Schifman, LG., Kanuk LL. 2007. Consumer Bahavior. International Edition. New Jersey: Pearson Education Inc.

Sen S., Bhattacharya CB. 2001. Does doing good always lead to doing better? Consumer reactions to corporate social responsibility. Journal of marketing Research, 38 (2), 225243.

Shah SK., Corley KG. 2006. Building Better Theory by Bridging the QuantitativeQualitative Divide. Journal of Management Studies, 43 (8), 1821-1835.

Trudel R., Cotte J. 2009. Does it pay to be good. MIT Sloan Management Review, 50 (2), 6168.

Undang-Undang No. 25 Tahun 2007 Tentang Penanaman Modal.

Undang-Undang No. 40 Tahun 2007 Tentang Perseroan Terbatas.

Webb \& Mohr. 1998. Do Consumer Expect Companies to be Socially Responsible? The Impact of CSR on Buying Behavior. The Journal of Consumer Affairs, Vol. 35, No. 1

Zdravkovic S., Magnusson P., Stanley, SM. 2010. Dimensions of fit between a brand and a social cause and their influence on attitudes. International Journal of Research in Marketing, 27(2), 151-160. 